\title{
Physico-chemical Evaluation of Drinking Water Quality in Alshati District of Libya
}

\author{
Mansour A. Salem ${ }^{1}$, Mohammed I. Alshergawi ${ }^{2}$ \\ Department of Environmental Sciences, Faculty of Engineering and Technology, Sebha University, Libya
}

\begin{abstract}
Abestract: The quality of groundwater of fifty one wells for drinking water from Alshati district was assessed for its suitability for drinking. Water samples were collected and analyzed for various physico-chemical parameters such as pH, Temperature $\left({ }^{\circ} \mathrm{C}\right)$, Electrical Conductivity (EC), Total Hardness (TH), Total Dissolved Solids (TDS), Alkalinity (Alk), Chloride (Cl), Iron $\left(\mathrm{Fe}^{++}\right)$, Manganese $\left(\mathrm{Mn}^{++}\right)$, Calcium $\left(\mathrm{Ca}^{++}\right)$, Magnesium $\left(\mathrm{Mg}^{++}\right)$, Nitrate $\left(\mathrm{NO}_{3}^{-}\right)$, Sodium $\left(\mathrm{Na}^{+}\right)$, Potassium $\left(\mathrm{K}^{+}\right)$, Sulphate $\left(\mathrm{SO}_{4}^{--}\right)$and Phosphate $\left(\mathrm{PO}_{4}^{--}\right)$. The results revealed that some parameters of water samples were out of limit according to the WHO standards and Libyan standards for drinking water. The results shows rising of $\mathrm{Fe}^{++}$and $\mathrm{Mn}^{++}$in most of the wells studied, rising of $\mathrm{Ca}^{++}$in water samples of wells of Al-Mansura and Abu-gadgud, rising of $\mathrm{SO}_{4}^{--}, \mathrm{TDS}$ and EC in water samples of wells of Idri, and rising of $\mathrm{Cl}^{-}$in water samples of Idri, Waanzarik, Taamasan, Al-Mansura and Al-kadra. $\mathrm{NO}_{3}{ }^{-}$was also rising in water samples of wells of Mahruga and Bergen.
\end{abstract}

Keywords - Groundwater, Alshati district, physico-chemical parameters, WHO standard

\section{Introduction}

Ground water is the sole source of drinking water in Alshati district in Libya. It is the major source of water supply for domestic purposes in this area. The quality and purity of ground water has direct effect on human life. The problem of ground water quality is more acute and can be seen obviously in highly populated areas [1,2]. Shortage of drinking water worldwide is becoming very acute nowadays. A bout $2.5 \%$ of earth's water is fresh and potable for human use. The ground water represents $13 \%$ of this water. Ground water has been used for drinking for a long time due to its purity and has made it very important source for potable water widely. [3]. Heavy using of ground water in urbanization places along coastlines and estuaries will have a large impact on the quantity and the quality of aquifer water. [4]. In arid and semiarid regions, groundwater is the primary source of water. It has been estimated that at least one - fourth of the world's population obtain their water from underground aquifers. [5]. The world's largest aquifers are located in these regions and its limited recharge makes them highly susceptible to groundwater depletion. [6]. It has been believed that ground water is pure and safer than surface water. Although the presence of more than 200 chemical constituents has been documented in it, the source of these chemicals are both naturally or/and anthropogenic [7]. Ground water quality can be contaminated and become unsafe for drinking and domestic uses as a result of lack of proper amenities in many societies, which can lead to the contamination of ground water with different bacteria including pathogens, especially in the high-density residential areas where sewage disposal practices are not proper. $[8,9]$. An excessive amount of arsenic, fluoride, nitrate, sulphate, salinity and heavy metals has been reported in different parts of India. [10]. Ground water in surrounding area of industries usually contains higher levels of heavy metals such as lead, copper and cadmium. Industrial effluents released on the land or dumped in the surface water which ultimately leaches to ground water leading to the contamination of water due to its accumulation in high concentration and cause a series of problems in living [11]. Contamination of ground water due to human activities can lead to adverse effects on the health of mankind and ecosystems. [12]. Once the ground water polluted at site, it may remain unusable or even hazardous for decades of centuries. Low velocity of ground water is a crucial factor for mixing or diluting of these contaminates, consequently a contaminant plume may maintain a high concentration as it slowly moves from points of recharge to zone of discharge [13]. Ground water can also be contaminated as a result of disposal of fluids through wells in lime stone terrains as well as (or) through sinkholes directly into aquifers. Infiltration of contaminated surface water has caused contamination of ground water in many places and raised the degree of contamination related to the hydrologic properties of the aquifer, type and amount of waste, climate and disposal method. An excessive of water pumping may lead to deterioration of ground water quality as a result of migration of more mineralized water from surrounding strata to the well [14 - 16]. In India, 77\% of surface water resources and large number of ground water reserves are already contaminated by biological, organic and inorganic pollutants. [17, 18]. Urbanization, climate changes and increase of the world's populations are the main factors for the limiting of fresh water resources as a result of increasing of water demand and pollution of fresh water ecosystems [19, 20]. Ground water represents the main source of fresh water in Libya. Its availability and quality is vulnerable to climate changes and over-abstraction. Shortage resources of water in Libya reduce its ability to maintain its 
quality especially if there are different sources of pollutants [21]. Ground water is the only source of water supply for drinking, agricultural and other purposes. $90 \%$ of water supply comes from underground water while the $10 \%$ comes from other sources [22]. Water unavailability, depletion of underground water as a result of overuse in agricultural developments cause salinity and sea-water penetration into the coastal aquifers are the major concerns in Libya.

\section{Materials And Methods}

Alshati district is located in Southern - West corner of Libya between North latitude $27^{\circ}$ to $27.4^{\circ}$ and East longitude $13^{\circ}$ to $14.30^{\circ}$, it is area is about $97160 \mathrm{Km}^{2}$, (fig. 1), and the population of it is about 80,000 .

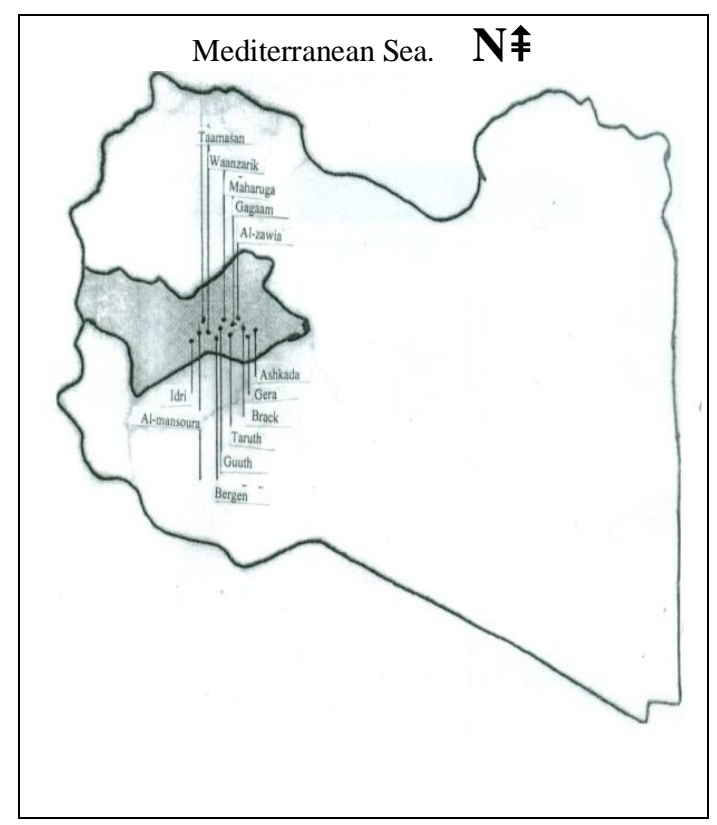

Fig. 1. Map of Libya showing Alshati district and the places from where the samples collected

The ground water samples were collected from fifty one wells of different places randomly in Alshati district these wells represented all drinking wells in Alshati. Water samples were collected in polythene bottles as per standard procedure in January 2009. Samples were analyzed for sixteen parameters including, pH, Temperature, Electrical Conductivity, Total Hardness, Total Dissolved Solids, Alkalinity, Chloride, Iron, Manganese, Calcium, Magnesium, Nitrate, Sodium, Potassium, Sulphate and Phosphate. Temperature, electrical conductivity and total dissolved solids were measured immediately on site after sampling using Hanna auto ranging microprocessor EC/TDS $/{ }^{\circ} \mathrm{C}$ while the $\mathrm{pH}$ measured by Beckman $\mathrm{pH}$ meter. Nitrate concentration was determined by spectrophotometer. Sodium and Potassium was analyzed using Flame photometer. The other physico-chemical parameters were analyzed in the laboratory using the standard methods. [23]

\section{Results And Discussion}

A comparison of the physico-chemical characteristics of the studied water samples of drinking water wells has been made with $[24,25]$ Table 1 , Collected data revealed that there were considerable variations in physico - chemical properties of examined samples from the different localities. Temperature of water samples were ranging from $22.6-30.08^{\circ} \mathrm{C}$. Biological activities and growth can be greatly affected by temperature, other parameters such as $\mathrm{pH}, \mathrm{EC}$, dissolving oxygen and water chemistry can also influenced by high temperature [ 3]. The $\mathrm{pH}$ of the water samples were varying from 6.32 to 7.67 which lies within the limits of WHO standards for drinking water quality. WHO (2000). The $\mathrm{pH}$ value of drinking water is an important index of acidity or alkalinity, $\mathrm{pH}$ of ground water influenced by geology of catchment area and buffering capacity of water [26]. $\mathrm{EC}$ of the water samples were ranging between $\left(117-2214 \mu \mathrm{mhos} . \mathrm{cm}^{-1}\right)$ which revealed a large variation in EC. High EC were found in water samples of Taamasan, Al-Mansoura and in both the wells of Idri. The desirable limit set for natural water by WHO (2000). [27] should not exceed $1400 \mu \mathrm{mhos}_{\mathrm{cm}}{ }^{-1}$. It has been reported that EC is affected by the presence of TDS and Temperature, high value of EC is correlated with high TDS [28, 29]. $\mathrm{EC}$ is an important parameter in assessing water quality for drinking and irrigation purposes. EC is used as an indicator and classification of salinity. High values of EC in ground water are due to high dissolved solids. Therefore high EC means high degree of salinity and an index of the amount of dissolved substances in water [30]. The results show good positive correlation between $\mathrm{EC}, \mathrm{Cl}^{-}, \mathrm{Na}^{+}$, TDS and $\mathrm{SO}_{4}{ }^{--}$. The correlation $(\mathrm{r}=$ $0.877,0.872,0.956$ and 0.936 ) respectively. These results suggested that $\mathrm{Cl}^{-}, \mathrm{Na}^{+}$, TDS and $\mathrm{SO}_{4}^{--}$greatly 
influenced the EC and agreed with the results reported by [7, 27]. Total dissolved solids (TDS) of collected water samples were ranging between $345-1411 \mathrm{mg} . \mathrm{l}^{-1}$, all samples were under standard limits except Idri site which recorded more than $1400 \mathrm{mg} . \mathrm{l}^{-1}$. According to Libyan standards for drinking water, TDS should not exceed $1000 \mathrm{mg} \cdot \mathrm{I}^{-1}$. TDS is one of the main characteristics that decide the quality of drinking water. The results showed positive correlation between TDS and $\mathrm{EC}, \mathrm{Cl}^{-}, \mathrm{Ca}^{++}, \mathrm{Na}^{+}$and $\mathrm{SO}_{4}^{--}$were the correlation $(\mathrm{r}=0.956$, $0.926,0.4,0.94$ and 0.967 ) respectively. High levels of TDS might be due to contamination of ground water as result of discharge of waste waters into pits and pods [31]. These results were also consistent with the results by $[7,27]$. The results show that total hardness of all water samples was varying from $88-309 \mathrm{mg} . \mathrm{l}^{-1}$. These values were lay within the standard limit of WHO (2000) and Libyan standards for drinking water which permit any value less than $500 \mathrm{mg} . \mathrm{l}^{-1}$. The results show positive correlation between $\mathrm{TH}$ and $\mathrm{Ca}^{++}$and $\mathrm{Mg}^{++}(\mathrm{r}=0.535$ and 0.514) respectively, which revealed the dependence of $\mathrm{TH}$ on $\mathrm{Ca}^{++}$and $\mathrm{Mg}^{++}$, this is consistent with the results reported by $[7,32]$. Total hardness is an important parameter of water quality to be used for any purpose. It had been reported that water hardness in most ground water is naturally occurring from weathering of limestone, sedimentary rock and calcium bearing minerals or as a result of an application of lime to the soils in agricultural areas [27]. Total alkalinity of studied water samples were ranged from $64-142 \mathrm{mg} \cdot \mathrm{l}^{-1}$. These values of alkalinity were lay within the permit values of Libyan standards for drinking water and WHO (2000) standard. Results show a correlation between Alk and $\mathrm{Cl}^{-}, \mathrm{TH}, \mathrm{Na}^{+}$, TDS, and $\mathrm{SO}_{4}^{-}{ }^{-}(\mathrm{r}=0.372,0.314,0.432,0.342$ and 0.422$)$ respectively. Alkalinity in water gives an idea of natural salts present in it. High alkalinity is a result of dissolve of various ionic species such as bicarbonate, hydroxide, phosphate, borate, organic acids and natural processes taking place at any certain time. [33]. Slight increasing of alkalinity values is not harmful to human beings health. [34]. Also, the results show that Chloride varied from $143-649 \mathrm{mg} . \mathrm{l}^{-1}$, the permissible limit for chloride in drinking water is up to $250 \mathrm{mg} \cdot \mathrm{l}^{-1}$ as reported by WHO (2000) and Libyan standards for drinking water. High concentration of chloride more than $\left(250 \mathrm{mg}^{-1} \mathrm{l}^{-1}\right)$ were found in water samples from Waanzarik, Al-kadara, Taamasan, Al-Mansoura and Idri. These places are located close to each other (fig. 1). Results show positive correlation between $\mathrm{Cl}^{-}$and $\mathrm{EC}, \mathrm{Na}^{+}, \mathrm{K}^{+}$, TDS, Alk, $\mathrm{SO}_{4}^{--}$and $\mathrm{PO}_{4}^{--}$. were $\mathrm{r}=0.877,0.963,0.54,0.925,0.372$, 0.891 and 0.53 respectively. High chloride value in ground water gives salt tastes to water and possibly due to minerals like apatite and mica or might be from liquid inclusions in the igneous rocks. [35]. These results were agree with the results reported by [7]. Sulphate content in ground water samples were ranged from $19-440$ mg. $\mathrm{l}^{-1}$. In some places, sulphate concentration exceeded the permissible limits of sulphate $250 \mathrm{mg} \cdot \mathrm{l}^{-1}$. WHO (2000). Libyan standard for sulphate is $400 \mathrm{mg} \cdot \mathrm{l}^{-1}$. Results show high positive correlation between $\mathrm{SO}_{4}^{--}$and EC, $\mathrm{Cl}^{-}, \mathrm{Na}^{+}$and TDS were $\mathrm{r}=0.936,0.891,0.901$ and 0.967 respectively. $\mathrm{SO}_{4}^{--}$also correlated with $\mathrm{Ca}^{++}, \mathrm{Na}^{+}$and Alk were $\mathrm{r}=0.41,0.357$ and 0.38 respectively. These are the same places where we found high values of chloride. Therefore we believe that there is a relationship between high concentration of chloride and sulphate. Sulphate may be present in sedimentary rocks and in minor quantities in igneous rocks; therefore concentration of sulphate may occur in wide range in nature [7]. These results were consistent in some extent with the results reported by [7,27]. Sodium concentration in ground water samples collected was found in between $57.4-126.9$ $\mathrm{mg} . \mathrm{l}^{-1}$. According Libyan standards for drinking water, sodium concentration $\left(<200 \mathrm{mg} \cdot \mathrm{l}^{-1}\right)$ is lay within the permissible limit for sodium. Whereas according the WHO (2000) standards for sodium content in water samples should not exceed $50 \mathrm{mg} . \mathrm{l}^{-1}$. The results show positive correlation between $\mathrm{Na}^{+}$and $\mathrm{EC}, \mathrm{Cl}^{-}$, TDS and $\mathrm{SO}_{4}^{--}$were $\mathrm{r}=0.872,0.963,0.94$ and 0.901 respectively. These results were agreed with the results obtained by [7, 27]. According WHO 2000 Sodium is high in all locations Sodium content has been found higher than permissible limit in all water samples. Sodium is a naturally occurring element and can be added to the ground water from industrial and domestic wastes. It is one of the major contributors to salinity of water. High sodium concentrations were found in ground water samples in Panipat city in India [7]. The results show that nitrate concentration in water samples were ranged between 0.01- 92 mg. $\mathrm{l}^{-1}$, WHO (2000) recommended safe permissible limit for nitrate is up to $50 \mathrm{mg} . \mathrm{l}^{-1}$. High content of nitrate 80.95 and $92 \mathrm{mg} . \mathrm{l}^{-1}$ were observed in ground water samples from Bergin area and Mahruga respectively. Positive correlations were observed between $\mathrm{NO}_{3}{ }^{-}$and $\mathrm{Ca}^{++}$and $\mathrm{Mg}^{++}$were $\mathrm{r}=0.33$ and 0.514 respectively. It had been reported that $\mathrm{NO}_{3}{ }^{-}$is positively correlated with $\mathrm{K}^{+}$. This result differs with the results obtained by [27]. Nitrate is highly soluble element and had an anionic form. Therefore it can be easily leached into the water table. The most sources of nitrate contamination in ground water are atmospheric fallout, organic and sewage pollution and agriculture activities [36]. Potassium in all ground water samples were within the desirable limits set by Libyan standards for drinking water. It ranged between $10.3-34.3 \mathrm{mg} \cdot \mathrm{l}^{-1}$. The results shows correlation between $\mathrm{K}^{+}$and $\mathrm{EC}, \mathrm{Cl}^{-}, \mathrm{Na}^{+}$, TDS, $\mathrm{SO}_{4}^{--}$and $\mathrm{PO}_{4}^{--}, \mathrm{r}=0.434,0.54,0.431,0.437,0.357$ and 0.355 . Sources of potassium in natural ground water are due to weathering of rocks and disposal of waste water can also increase its concentrations in fresh water [3]. Manganese in ground water samples were ranged between $0.01-1.83 \mathrm{mg} \cdot \mathrm{l}^{-1}$. According Libyan standard for drinking water and WHO 2000, the permissible limit of manganese is up to 0.1 and $0.5 \mathrm{mg} .1^{-1}$ respectively. The results show that $92 \%$ of the studied ground water samples contain more than the recommended value, where it recorded $1.83 \mathrm{mg} . \mathrm{l}^{-1}$ in Brack area, whereas water samples from Al-zawia, Abu- 
gadgud, Bergin and Al-Mansoura contains less than permissible limit, $\mathrm{Mn}^{++}$was not significantly correlated with any of the analyzed parameters. This result is consistent with the results obtained by [7]. High concentration of Iron was recorded in $82.4 \%$ of studied ground water samples. Up to $6.94 \mathrm{mg} . \mathrm{l}^{-1}$ has been reported in Idri. $\mathrm{Fe}^{++}$shows positive correlation with $\mathrm{PO}_{4}^{--}(\mathrm{r}=0.48)$. The permissible limits of $\mathrm{Fe}^{++}$prescribed by Libyan standard for drinking water and WHO (2000) is up to $0.3 \mathrm{mg}, \mathrm{l}^{-1}$ [3]. We think the presence of high concentrations of $\mathrm{Fe}^{++}$in the area referred to the geological criteria of Alshati area, where Iron is precipitated in the ground. High concentrations of Phosphate $\left(\mathrm{PO}_{4}^{--}\right)$were also recorded in $88 \%$ of collected underground water samples, Up to $15 \mathrm{mg} . \mathrm{l}^{-1}$ were recorded in Idri. Permissible limit of phosphate in drinking water is up to 0.01 $\mathrm{mg}, \mathrm{l}^{-1}$ as it has been mentioned by [3]. The results show positive correlation between $\mathrm{PO}_{4}^{--}$and $\mathrm{EC}, \mathrm{Cl}^{-}, \mathrm{Fe}^{++}$, $\mathrm{Na}^{+}, \mathrm{K}^{+}$, TDS and $\mathrm{SO}_{4}^{--}$, the value of $\mathrm{r}=0.421,0.53,0.48,0.46,0.355,0.433$ and 0.422 respectively. Calcium in water samples were ranged between $11.2-333 \mathrm{mg} \cdot \mathrm{l}^{-1}$. According to WHO (2000) permissible limit for $\mathrm{Ca}^{++}$is up to $100 \mathrm{mg} \cdot \mathrm{l}^{-1}$. While it is $200 \mathrm{mg} . \mathrm{l}^{-1}$ in Libyan standards for drinking water, results show high concentration of $\mathrm{Ca}^{++}$in Abu-gadgoud and Al-Mansoura were the concentration of $\mathrm{Ca}^{++}$recorded 276 and $333 \mathrm{mg} . \mathrm{l}^{-1}$ respectively. $\mathrm{Ca}^{++}$shows positive correlation with $\mathrm{Mg}^{++}$, $\mathrm{TH}, \mathrm{SO}_{4}{ }^{--}$and TDS were $\mathrm{r}=0.848,0.535,0.4$ and 0.4 respectively. There is some kind of correlation between $\mathrm{Ca}^{++}, \mathrm{NO}_{3}{ }^{-}$and $\mathrm{Na}^{+}$were $\mathrm{r}=0.33$, and 0.37 too. $\mathrm{Ca}^{++}$is commonly present in all water bodies [3]. This result is consistent with the results reported by [27]. The results shows that Magnesium concentration is ranged between $3.36-57.6 \mathrm{mg} .1^{-1}$. The acceptable limit for $\mathrm{Mg}^{++}$is up to $150 \mathrm{mg} . \mathrm{l}^{-1}$ as described by WHO (2000) and Libyan standards for drinking water. $\mathrm{Ca}^{++}$and $\mathrm{Mg}^{++}$are combined to form total hardness [27]. $\mathrm{Mg}^{++}$shows positive correlation with $\mathrm{Ca}^{++}$and $\mathrm{TH}$ were $\mathrm{r}=0.848$ and 0.514 respectively.

Table 1. MANIMIUM AND MAXIMIUM VALUES OF MEASURED PHYSICO CHEMICAL PARAMETERS COMPARED TO WHO 2000 AND LIBYAN DRINKING WATER STANDARDS 1992

\begin{tabular}{|c|c|c|c|c|}
\hline \multirow[t]{2}{*}{ Parameter } & \multicolumn{2}{|c|}{ standards of drinking water } & \multicolumn{2}{|c|}{ Results } \\
\hline & Libyan & WHO (2000) & Minimum & Maximum \\
\hline $\mathrm{PH}$ & $6.5-8.5$ & $6.5-9.5$ & 6.32 & 7.67 \\
\hline${ }^{\circ} \mathrm{C}$ & $*$ & $*$ & 19.4 & 30.8 \\
\hline $\mathrm{EC} \mu \mathrm{mhos} . \mathrm{cm}^{-1}$ & ** & 1400 & 117 & 2214 \\
\hline TDS mg.l ${ }^{-1}$ & Up to1000 & 600 & 354 & 1411 \\
\hline $\mathrm{Fe}^{++} \mathrm{mg}^{-l^{-1}}$ & 0.3 & 0.3 & 0.01 & 6.94 \\
\hline $\mathrm{Mg}^{++} \mathrm{mg} \cdot \mathrm{l}^{-1}$ & 150 & 150 & 3.36 & 57.6 \\
\hline $\mathrm{Na}^{+} \mathrm{mg} \cdot \mathrm{l}^{-1}$ & 200 & - & 57.39 & 126.86 \\
\hline $\mathrm{K}^{+} \mathrm{mg} . \mathrm{l}^{-1}$ & 40 & - & 10.29 & 34.29 \\
\hline $\mathrm{SO}_{4}^{--} \mathrm{mg} \cdot \mathrm{l}^{-1}$ & 400 & 250 & 19.12 & 440.12 \\
\hline $\mathrm{Ca}^{++} \mathrm{mg}^{-l^{-1}}$ & 200 & 100 & 11.2 & 332.8 \\
\hline $\mathrm{Cl}^{-} \mathrm{mg} \cdot \mathrm{l}^{-1}$ & 250 & 250 & 143 & 648.9 \\
\hline TH mg. $\mathrm{l}^{-1}$ & 500 & 500 & 88 & 309 \\
\hline $\mathrm{NO}_{3}^{-} \mathrm{mg} \cdot \mathrm{l}^{-1}$ & 45 & 50 & 0.01 & 91.97 \\
\hline $\mathrm{Mn}^{++} \mathrm{mg} \cdot \mathrm{l}^{-1}$ & 0.1 & 0.5 & 0.01 & 1.83 \\
\hline Alk mg. $1^{-1}$ & 200 & - & 64 & 142 \\
\hline $\mathrm{PO}_{4}^{--} \mathrm{mg} \cdot \mathrm{l}^{-1}$ & $* *$ & $* *$ & 0.01 & 43.31 \\
\hline
\end{tabular}

* There is no standard limit. ** Not mentioned, - not mentioned, Alk limit. Sherma (2004)

Table 2: Correlation matrix among sixteen water quality parameters of ground water of study area

\begin{tabular}{|c|c|c|c|c|c|c|c|c|c|c|c|c|c|c|c|c|}
\hline & $\mathrm{C}$ & $\mathrm{PH}$ & EC & $\mathrm{Cl}^{-}$ & $\mathrm{Fe}^{+}$ & $\underset{++}{\mathrm{Mn}}$ & $\mathrm{Ca}^{++}$ & $\underset{+}{\mathrm{Mg}^{+}}$ & $\mathrm{TH}$ & $\mathrm{NO}_{3}^{-}$ & $\mathrm{Na}^{+}$ & $\mathrm{K}^{+}$ & TDS & $\begin{array}{c}\mathrm{Al} \\
\mathrm{k}\end{array}$ & $\mathrm{SO}_{4}^{--}$ & $\mathrm{PO}_{4}$ \\
\hline C & 1 & & & & & & & & & & & & & & & \\
\hline pH & 5 & 1 & & & & & & & & & & & & & & \\
\hline EC & $\begin{array}{l}0.10 \\
3\end{array}$ & $\begin{array}{l}0.21 \\
6\end{array}$ & $\begin{array}{l}1 \\
0.87\end{array}$ & & & & & & & & & & & & & \\
\hline $\mathrm{Cl}^{-}$ & $\begin{array}{l}0.13 \\
-\end{array}$ & $\begin{array}{l}0.03 \\
-.\end{array}$ & $\stackrel{7}{*}^{*}$ & $\begin{array}{l}1 \\
0.19\end{array}$ & & & & & & & & & & & & \\
\hline $\mathrm{Fe}^{++}$ & $\begin{array}{l}0.26 \\
-\end{array}$ & $\begin{array}{l}0.17 \\
-\end{array}$ & $\begin{array}{l}0.14 \\
-\end{array}$ & $\begin{array}{l}5 \\
-\end{array}$ & $\begin{array}{l}1 \\
0.2\end{array}$ & & & & & & & & & & & \\
\hline Mn & $\mathbf{0 . 3 6}$ & 0.33 & 0.19 & 0.05 & 1 & 1 & & & & & & & & & & \\
\hline
\end{tabular}




\begin{tabular}{|c|c|c|c|c|c|c|c|c|c|c|c|c|c|c|c|c|}
\hline $\begin{array}{l}\mathrm{Ca}^{+} \\
+\end{array}$ & $\begin{array}{l}- \\
0.19\end{array}$ & 0.00 & 0.38 & $\begin{array}{l}0.26 \\
8\end{array}$ & $\begin{array}{l}- \\
0.2 \\
5 \\
-\end{array}$ & $\begin{array}{l}-0.2 \\
-\end{array}$ & 1 & & & & & & & & & \\
\hline $\mathbf{M g}_{+}^{\mathbf{M g}^{+}}$ & $\begin{array}{l}- \\
0.14 \\
-\end{array}$ & $\begin{array}{l}- \\
0.02 \\
-\end{array}$ & $\begin{array}{l}0.10 \\
2 \\
0.16\end{array}$ & $\begin{array}{l}0.03 \\
4 \\
0.21\end{array}$ & $\begin{array}{l}0.1 \\
6 \\
0.1\end{array}$ & $\begin{array}{l}0.2 \\
6\end{array}$ & $\begin{array}{l}0.84 \\
8^{*} \\
0.53\end{array}$ & $\begin{array}{l}1 \\
0.51\end{array}$ & & & & & & & & \\
\hline TH & 0.29 & 0.16 & 9 & 9 & 3 & $\begin{array}{l}0.1 \\
-\end{array}$ & 5 & 4 & 1 & & & & & & & \\
\hline $\mathrm{NO}_{3}$ & -0.2 & $\overline{0 .}$ & $\begin{array}{l}0.02 \\
6\end{array}$ & $\begin{array}{l}0.08 \\
2\end{array}$ & $\begin{array}{l}\text { 0.0 } \\
4\end{array}$ & $\begin{array}{l}0.1 \\
3 \\
-\end{array}$ & 0.33 & 0.4 & $\begin{array}{l}0.18 \\
6\end{array}$ & 1 & & & & & & \\
\hline $\mathrm{Na}^{+}$ & $\overline{0}$ & -0.1 & $\begin{array}{l}0.87 \\
2^{*}\end{array}$ & $\begin{array}{l}0.96 \\
3^{*}\end{array}$ & $\begin{array}{l}0.1 \\
5\end{array}$ & $\begin{array}{l}\text { 0.0 } \\
9\end{array}$ & 0.37 & 0.15 & $\begin{array}{l}0.35 \\
5 \\
-\end{array}$ & $\begin{array}{l}0.15 \\
8\end{array}$ & 1 & & & & & \\
\hline $\mathbf{K}^{+}$ & 0.07 & $\begin{array}{l}\text { 0.00 } \\
7\end{array}$ & $\begin{array}{l}0.43 \\
4\end{array}$ & 0.54 & $\begin{array}{l}0.2 \\
-\end{array}$ & $\begin{array}{l}0.2 \\
71 \\
-\end{array}$ & $\overline{0}$ & $\overline{0} \overline{0.65}$ & $\begin{array}{l}0.17 \\
4\end{array}$ & $\overline{0} .26$ & $\begin{array}{l}0.43 \\
1\end{array}$ & 1 & & & & \\
\hline $\begin{array}{l}\text { TD } \\
\mathbf{S}\end{array}$ & $\begin{array}{l}0.02 \\
9\end{array}$ & $\begin{array}{l}0.03 \\
1\end{array}$ & $\begin{array}{l}0.95 \\
6^{*}\end{array}$ & $\begin{array}{l}0.92 \\
6^{*}\end{array}$ & $\begin{array}{l}\mathbf{0 . 0} \\
2\end{array}$ & $\begin{array}{l}0.1 \\
4 \\
-\end{array}$ & 0.4 & $\begin{array}{l}0.14 \\
2\end{array}$ & $\begin{array}{l}0.23 \\
3\end{array}$ & $\begin{array}{l}0.07 \\
2 \\
-\end{array}$ & $\begin{array}{l}\mathbf{0 . 9 4} \\
*\end{array}$ & $\begin{array}{l}\mathbf{0 . 4} \\
37\end{array}$ & 1 & & & \\
\hline Alk & $\overline{0.26}$ & $\overline{0} .07$ & 0.31 & $\begin{array}{l}0.37 \\
2\end{array}$ & $\begin{array}{l}0.1 \\
2 \\
-\end{array}$ & $\begin{array}{l}\mathbf{0 . 0} \\
8 \\
-\end{array}$ & $\begin{array}{l}0.16 \\
7\end{array}$ & $\begin{array}{l}0.02 \\
6\end{array}$ & $\begin{array}{l}0.31 \\
4\end{array}$ & $\begin{array}{l}0.16 \\
4\end{array}$ & $\begin{array}{l}0.43 \\
2\end{array}$ & $\begin{array}{l}0.0 \\
62\end{array}$ & $\begin{array}{l}0.34 \\
2\end{array}$ & 1 & & \\
\hline $\mathrm{SO}_{4}^{-}$ & $\begin{array}{l}0.05 \\
5\end{array}$ & $\begin{array}{l}0.05 \\
1\end{array}$ & $\begin{array}{l}0.93 \\
6^{*}\end{array}$ & $\begin{array}{l}0.89 \\
1^{*}\end{array}$ & $\begin{array}{l}0.0 \\
2\end{array}$ & $\begin{array}{l}0.1 \\
7 \\
-\end{array}$ & 0.4 & 0.14 & $\begin{array}{l}0.16 \\
6 \\
-\end{array}$ & $\begin{array}{l}\text { 0.07 } \\
\mathbf{3}\end{array}$ & $\begin{array}{l}0.90 \\
1 *\end{array}$ & $\begin{array}{l}0.3 \\
57\end{array}$ & $\begin{array}{l}0.96 \\
7 *\end{array}$ & $\begin{array}{l}0 . \\
38\end{array}$ & 1 & \\
\hline $\mathrm{PO}_{4}$ & $\begin{array}{l}0.14 \\
4 \\
\end{array}$ & $\begin{array}{l}0.25 \\
8 \\
\end{array}$ & $\begin{array}{l}0.42 \\
1 \\
\end{array}$ & $\mathbf{0 . 5 3}$ & $\begin{array}{l}0.4 \\
8 \\
\end{array}$ & $\begin{array}{l}0.1 \\
8 \\
\end{array}$ & $\overline{\mathbf{0}} \mathbf{0 . 1 5}$ & $\overline{\mathbf{0}} \mathbf{0 . 1 7}$ & $\begin{array}{l}0.03 \\
9 \\
\end{array}$ & $\overline{\mathbf{0}} \mathbf{0 . 0 9}$ & 0.46 & $\begin{array}{l}0.3 \\
55 \\
\end{array}$ & $\begin{array}{l}0.43 \\
3 \\
\end{array}$ & $\begin{array}{l}0 . \\
15 \\
\end{array}$ & $\begin{array}{l}0.42 \\
2 \\
\end{array}$ & 1 \\
\hline
\end{tabular}

\section{Conclusion}

The present study aimed to evaluate the suitability of underground water of Alshati area for drinking, on the basis of present physico - chemical analysis of samples of ground water of Alshati district. According to the findings, we come to the conclusion that the ground water quality of the district varies from place to place. High values of some chemical elements were observed in the west part of the district. The results show high concentrations of EC, TDS, $\mathrm{Cl}^{-}, \mathrm{Fe}^{++}, \mathrm{Mn}^{++}, \mathrm{Ca}^{++}, \mathrm{NO}_{3}{ }^{-}, \mathrm{SO}_{4}^{--}$and $\mathrm{PO}_{4}^{--}$at certain locations which indicate that the ground water of these specific locations is not suitable for drinking and needed primary treatment. High values of some chemical parameters are signs of the deterioration of the water quality.

\section{Acknowledgements}

The authors would like to thank the authorities of University of Sebha, Libya for their technical support, and providing the necessary laboratory facilities.

\section{References}

[1] S, Gupta, A. Kumar, C. K. Ojha and G. Seth, Chemical analysis of ground water of Sanganer area, Jaipur in Rajasthan, J. Environ. Sci. Eng, 46, 2004, 74 - 78

[2] K. L Prakash and R.K. Somasheker, Ground water quality assessment on Anekal Taluk, Bangalore urban district, India. J. Environ. Biol. 27, 2006, 633 - 637.

[3] Deepali and N. Joshi, Study of ground water quality in and around Sidcul industrial area, HARIDWAR, UTTARAKHAND, India. J. of Appl. Tech. in Environ. Sant. 2(2), 2012, $129-134$.

[4] E, Campell and G. Bate, Groundwater in the Alexandria dune field and its potential influence on the adjacent surf-zone. Water SA. 17, $\quad 1992,155-160$.

[5] W. B. White, D.C. Culver, J.S. Herman, T.C. Kane and J.E. Mylroie, Karst lands. American Scientists, 83, 1995 , 450 - 459.

[6] R. B. Jackson, S. R. Carpenter, C.N. Dahm, D.M. Mcknight, R.J. Naiman, S. I. Postal and S.W. Running, Water in a changing world. Ecological Applications, 11(4), 2001, 1027-1045.

[7] M. Bishnoi and R. Malik, Ground water quality in environmentally degraded localities of Panipat city, India. J. of Environ. Biol. 29(6), 2008, $881-886$.

[8] C. P. Anand, A. Pratima and C. Rina, Bacteriological water quality status of river Yamuna in Delhi, J. Environ. Biol. 27, 2006, 97 107.

[9] R. Krishnan, K. Radha, Dhamara and B.D. Ranjiha Kumar, A comparative study on the physicochemical and bacterial analysis of drinking, bore well and sewage water in the three different places of Sivakasi, J. Environ. Biol. 28, $2007,695-700$.

[10] V. K. Meenakshi, K. Renuk, and A. Malik, Groundwater quality in some villages of Haryana, India. Focus on fluoride and fluoresis, J. Hazards Matr. 106, 2004, $85-87$.

[11] M. Malarkodi, R. Krishnasamy, R. Kumaraperumal, R and T. Chitdeshwari, Characterization of heavy metal contaminated soils of Coimbatore district in Tamil Nadu. J. of. Agro. 6(1), 2007, 147 - 151

[12] O. A Al-khashman, Study of water quality of springs in Petra region, Jordon: A three years follow up. Water Res. Manage. 21, 2007, $1145-1163$.

[13] W. A. Patty Johns, Groundwater pollution An imminent disaster. Groundwater, 17, 1979, 27 -51. 
[14] S.N. Kaual, A. U. Mahajan and T. Nady, Water and waste water treatment, recycle and reuse. J. Ind. Assoc. Environ. Manage. 26, 1999, $74-90$

[15] J. P. Yadav and S. Lata, Urinary fluoride levels and prevalence of dental fluorosis in children of Jhajar district, Haryana. Ind. J. Med. Sci. 57, 2003, $394-\quad 399$

[16] K. Shailaja and M.E.C. Johnson, Fluorides in ground water and its impact on health. J. Environ. Biol. $28,2007,331-332$.

[17] K. B. Bhatt and S. Salakani, Hydrochemistry of the upper Ganges River. Ind. J. Geol. Soc. India. 48, $1996,171-182$.

[18] K. B. Karnath, Groundwater Assessment, Development and Management, Tata McGraw- Hill Publishers, New Delhi, 1997).

[19] C. M, Pringle and M. Barber, The land - water interface science for a sustainable biosphere, Ecological Applications, 10, 2000 , 939 -940 .

[20] C. J. Vo to smarty, P. Green, J. Salisbury and R.B. Lammers, Global water resources: vulnerability from climate change and population growth, Science, $\quad 289,2000,284-288$.

[21] A. J. Jumma, E. M. Toriman and M.N. Hashim, Groundwater Pollution and Wastewater management in Derna City, Libya. Environ. J. Res. 6(1), 2012, $50 \quad-54$.

[22] M. M. Elabbar and F. A. Elmabrouk, Environmental impact assessment for desalination North and Tobouk desalination plants, Desalination, 185, 2005, 31-44.

[23] APHA. Standard methods for the analysis of water and waste water. $16^{\text {th }}$ edn. American Public Health Association, Washington D.C, 1985).

[24] WHO Guidelines for drinking water quality, 1, W.H.O. Geneva 2000).

[25] Libyan National Center for specifications and standards, Drinking water standards. No. 82, 1992.

[26] W. J. Jt. Weber and W. Stun, Mechanism of hydrogen ion buffering in natural waters. J. Amer. Water Works Assn. 55, 1963, 1533 1538 .

[27] K. D. Mudgal, M. Kumar and D. K. Sharma, Hydrochemical analysis of drinking water quality of Alwar district, Rajastan. Nat. and Sci. 7(2), 2009, 30- 39.

[28] M. Radojevic and V.N. Bashkin, Practical Environmental Analysis, R.S.C. Royal Society of Chemistry, UK, 1999, 166 - 169.

[29] H. J. O'Neill, M. McKim, J. Allen and J. Choate, Monitoring surface water quality: A guide for citizens, students and communities in Atlantic. Canada. Canada - New Brunswick Water/Economy Arrangement, Environment Canada, $49,1994$.

[30] C. H. Srinivas, C. Piska, M. S. Venkatesan, S.N. Rao and R. R. Reddy, Studies on groundwater quality of Hyderabad. Pollution Res. 19(2), 2000, 285.

[31] D. F. Rani, G. Geetha and J. Ebanazar, The drinking water quality characteristics of live rural places in and around Thittagudi, Tamil Nadu, India. Poll. Res, 22(1), 2003, 111-115.

[32] M. K. Gupta, V. Singh, P. Rajvanshi, S. Srivastva and S. Dass, Fluoride in groundwater in at Agra. Indian J. Environ. Hlth. 36, $1994,43-46$.

[33] M. R. Sharma, Assessment of ground water quality of Hamirpur area in Himachal Pradesh. Poll. Res. vol. 23(1), 2004, 131 - 134.

[34] T. B. Singh, I. Bata and D. Singh, Assessment of groundwater quality of Ponta Sahib (H.P). Poll. Res. $18(1)$, $1999,111-114$.

[35] P. K. Das and Malik. S. B, Ground water of Khatra region of Bankura district, West Bangal: Some chemical aspects in reference to its utilization. J. Indian Water Resource Sci. 8, 1988, $31-41$.

[36] R. W. Ritzi, Wright. S. L., Mann. B and Chen. M, Analysis of temporal variability in hydro geochemical data used for multivariate analysis. Groundwater, 31, 1993, 221-229.

\section{Author's Profile:}

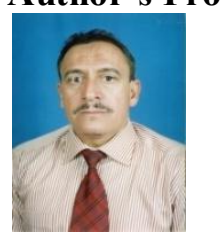

Mansour Awiedat Salem was born in Geera, Brack, Al Shaati, Libya in 1959. He has obtained both M.phil.(1993) and PhD (1996) in Biochemistry from Swansea University, Swansea, UK. He was the Head of the Department of Environmental Sciences, Faculty of Engineering and Technology, Sebha University, Libya from 1997 to 2005. Then, he joined as the Associate Professor and Dean of Faculty of Education, Brack, Al Shaati under the same University and still holding the position. He has published research papers entitled 'Nitrification in plants that also fix nitrogen in Nature (430, 98-101); 'Evaluaation of salinity in some soils of irrigated Brack-Ashkada agriculture project, Fezzan, Libya in IOSR Journal of Agr. and Vet. Sc.; 'NMR spectrum of 3-NPA extracted from four leguminous plants' in Chemistry Journal (vol.2, Issue 6); and 'A study of the presence of residual of nitrogenous fertilizer nitrate in some soils of Brack-Ashkida agriculture project' in Journal of life Sc. and Tech. (vol.1, no.1, March 2013, pp 84-89).

Dr.Awiedatss has received trainings in 'Operation and Using of Gas Chromatography' and 'Operation and Using of Atomic Absorption Spectroscopy'. He was the member of Environmental General Authority, Libya from 2007 to 2010 and also the Head of this office during 2010-2011.

Mohammed I. Alshergawi has obtained his Ph.D from Lancaster University, UK in 1990. He is Assistant Professor of Environmental Sciences Department at Faculty of Engineering and Technology Brack, Sebha University,

Libya. 